Brit. J. prev. soc. Med. (1976), 30, 138-140

\title{
Cancer in the offspring of fathers in hydrocarbon-related occupations
}

\author{
T. HAKULINEN, T. SALONEN, AND L. TEPPO \\ Finnish Cancer Registry, Institute for Statistical and Epidemiological Cancer Research, Helsinki, and \\ Third Department of Pathology, University of Helsinki, Finland
}

\begin{abstract}
Hakulinen, T., Salonen, T., and Teppo, L. (1976). British Journal of Preventive and Social Medicine, 30, 138-140. Cancer in the offspring of fathers in hydrocarbon-related occupations. A case-control study has been conducted to see whether a hydrocarbonrelated occupation of the father at the time of conception constitutes a risk factor for malignant disease in the offspring. The series comprised 852 cancer cases from the Finnish Cancer Registry and 852 controls matched for date of birth and domicile. The father's occupation for both the cases and controls was ascertained from the records of antenatal clinics. No significant associations were found between the commonest types of childhood cancer and hydrocarbon-related occupations-that is, motor-vehicle mechanics, machinists, miners, painters, and motor-vehicle drivers. Risk ratio 2 was excluded from most of the $95 \%$ confidence intervals for children under 15 years of age. The results do not support the hypothesis that there is an excess risk of cancer in the children of fathers in hydrocarbon-related occupations.
\end{abstract}

In a recent study, Fabia and Thuy (1974) introduced the 'hydrocarbon-related' occupation of the father at the time of birth of the child as being a risk factor for malignant neoplasm in the offspring. The occupations considered were motor-vehicle mechanic, service-station attendant, machinist, miner, lumberman, painter, dyer, and cleaner. The series comprised 386 children who had died of malignant diseases under the age of five during the years 1965-70 in Quebec, and a control group of 772 children whose birth registration immediately preceded or followed that of each case in the official files. Comparisons of the cases with the controls showed that the cases included a significant excess of fathers in hydrocarbon-related occupations; the relative risk was $2 \cdot 1$.

In a recent investigation from Finland (Salonen and Saxén, 1975), several variables were tested as risk indicators of childhood cancer. The antenatal and perinatal records of a series of 972 children who had contracted cancer before the age of 15 years were compared with those of a control series. The fathers' occupations were recorded during the study, but not included in the analyses. In the present investigation, this recorded information was used for testing the hypothesis of Fabia and Thuy (1974).

\section{Material AND Methods}

The primary series comprised all cases of $\stackrel{2}{\Rightarrow}$

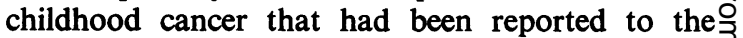
Finnish Cancer Registry during the years 1959-68. $\bar{J}$ This registry covers the entire country; it receives reports of cases of malignant neoplasms from hospitals, practitioners, and pathology laboratories, $\stackrel{\odot}{\stackrel{\odot}{\odot}}$ together with information derived from death certificates (Teppo et al., 1975a). Since various 3 . check-ups have indicated that the number of cases not reported to the registry is negligible, it can 3 be assumed that the series included all cases of childhood cancer diagnosed in Finland between 1959 and 1968 (Teppo, Salonen, and Hakulinen, 1975b).

For each case of cancer, a child whose date of ${ }^{N}$ birth was immediately before that of the case and $N$ who was born in the same maternity welfare N district, was selected as an individual control. As a ${ }^{\omega}$ consequence, the controls were matched for age, season of birth, and domicile. Sex was not included in the matching variables, as the authors wished to treat it as a study variable (Salonen and Saxén, 1975).

Since 1944, a country-wide, free antenatal care $\frac{0}{\mathrm{D}}$ system has been in operation in Finland. The $\frac{\mathcal{P}}{\mathbb{Q}}$ 
country is divided into some $\mathbf{2 0 0 0}$ maternity welfare districts, each of which has a centre headed by a physician, and operated by one or more trained nurses and/or midwives. The first contact is usually established during the twelfth to fourteenth week of pregnancy. In 1950 , the system covered $92.3 \%$ of all pregnant women in Finland, and since then the percentage of participation has gradually increased to reach nearly $100 \%$. A record is kept for each mother throughout her pregnancy and the father's occupation is noted on the first contact with the centre.

During the period 1959-68, the number of new malignant neoplasms in children under 15 years of age reported to the Finnish Cancer Registry was 1409. Because records were not available or information on the father's occupation was lacking, and the fact that twins were excluded, the final series comprised 852 pairs with indications of the occupations of the fathers of both the case and the control.

The analyses made related to three categories of malignant neoplasm: leukaemia and lymphomas (339 pairs), brain tumours (219 pairs), and other tumours (294 pairs). Two groups of occupations of possible high risk were identified using the classification of Fabia and Thuy (1974): motorvehicle mechanics, machinists, and miners (group I), and painters, dyers, and printers (group II). Motorvehicle mechanics were also analysed separately. In addition the study was extended to motor-vehicle drivers (group III), although no previous reports had been made on excess risk among the children of fathers in this occupation. Service-station attendants, lumbermen, and cleaners, who had been included among the 'hydrocarbon-related' occupations in the original report of Fabia and Thuy, were not represented among either the cases or the controls.
The results are given separately for the age groups $<5$ years and $<15$ years (the former being included in the latter). The risk ratios, together with the confidence intervals, were calculated using the method for individually-matched series (Miettinen, 1970a). The significance of the deviation between the observed risk ratio and 1 was determined by the application of McNemar's (or sign) test. In addition, a posteriori evaluation of matching (Miettinen, 1970b) was performed by calculating the correlations between the responses of the cases and those of the controls.

\section{RESULTS}

The proportions of the various hydrocarbonrelated occupations among the fathers of the cancer cases, and those of the controls, were of the same order in all three tumour categories (Table $I$ ). The proportions of occupations falling within groups I and II were rather small, and because the results proved to be similar in both, combined figures are presented.

The risk ratios did not differ significantly from 1 (Table II). The only risk ratio which clearly deviated from 1-occupations of groups I + II, brain tumours in children under five years of age (Table II)-was based upon only five discordant pairs. A risk ratio of 2 was excluded from most of the $95 \%$ confidence intervals for children under 15 years of age (Table II). With regard to occupations of groups I + II (mechanics, etc.), a risk ratio of 2 was not excluded in children of under five years of age. The risk ratios in respect of motor-vehicle mechanics only (all tumours) were $1.00(=3 / 3$, children $<5)$ and $1 \cdot 17(=7 / 6$, children $<15)$.

The correlations between the responses of cases and of controls were of the order $<0.1$, with the

TABLE I

PERCENTAGES OF SELECTED HYDROCARBON-RELATED OCCUPATIONAL GROUPS OF FATHERS OF CANCER CASES AND FATHERS OF CONTROLS, BY AGE OF CHILD, AND DIAGNOSIS

\begin{tabular}{|c|c|c|c|c|c|c|c|c|c|c|c|c|c|}
\hline \multirow{3}{*}{\multicolumn{3}{|c|}{ Diagnosis }} & \multirow{3}{*}{ Group } & \multicolumn{8}{|c|}{ Occupational Group* } & \multirow{2}{*}{\multicolumn{2}{|c|}{$\begin{array}{c}\text { Total No. } \\
\text { of Pairs }\end{array}$}} \\
\hline & & & & \multicolumn{2}{|c|}{ I } & \multicolumn{2}{|c|}{ II } & \multicolumn{2}{|c|}{ III } & \multicolumn{2}{|c|}{$\mathbf{I}+\mathbf{I I}+\mathbf{I I I}$} & & \\
\hline & & & & $<5$ & $<15$ & $<5$ & $<15$ & $<5$ & $<15$ & $<5$ & $<15$ & $<5$ & $<15$ \\
\hline Leukaemia and & mphomas & . & $\begin{array}{l}\text { Cases } \\
\text { Controls }\end{array}$ & $\frac{1 \cdot 3}{-}$ & $\begin{array}{l}1 \cdot 2 \\
0 \cdot 9\end{array}$ & $\overline{2 \cdot 5}$ & $\begin{array}{c}0 \cdot 3 \\
1 \cdot 8\end{array}$ & $\begin{array}{r}8 \cdot 9 \\
13 \cdot 3\end{array}$ & $\begin{array}{r}10 \cdot 3 \\
9 \cdot 7\end{array}$ & $\begin{array}{l}10 \cdot 1 \\
15 \cdot 8\end{array}$ & $\begin{array}{l}11 \cdot 8 \\
12 \cdot 4\end{array}$ & 158 & 339 \\
\hline Brain tumours & $\cdots$ & $\cdots$ & $\begin{array}{l}\text { Cases } \\
\text { Controls }\end{array}$ & $\begin{array}{l}1 \cdot 3 \\
1 \cdot 3\end{array}$ & $\begin{array}{l}2 \cdot 7 \\
2 \cdot 3\end{array}$ & $\frac{3 \cdot 9}{-}$ & $\begin{array}{l}2 \cdot 3 \\
1 \cdot 4\end{array}$ & $\begin{array}{r}5 \cdot 2 \\
11 \cdot 7\end{array}$ & $\begin{array}{r}7 \cdot 3 \\
10 \cdot 0\end{array}$ & $\begin{array}{l}10 \cdot 4 \\
13 \cdot 0\end{array}$ & $\begin{array}{l}12 \cdot 3 \\
13 \cdot 7\end{array}$ & 77 & 219 \\
\hline Other tumours & $\cdots$ & $\cdots$ & $\begin{array}{l}\text { Cases } \\
\text { Controls }\end{array}$ & $\begin{array}{l}1 \cdot 9 \\
2 \cdot 5\end{array}$ & $\begin{array}{l}1 \cdot 0 \\
2 \cdot 4\end{array}$ & $\begin{array}{l}2 \cdot 5 \\
1 \cdot 9\end{array}$ & $\begin{array}{l}2 \cdot 0 \\
2 \cdot 0\end{array}$ & $\begin{array}{r}11 \cdot 9 \\
9 \cdot 4\end{array}$ & $\begin{array}{r}11 \cdot 2 \\
8 \cdot 2\end{array}$ & $\begin{array}{l}16 \cdot 3 \\
13 \cdot 8\end{array}$ & $\begin{array}{l}14 \cdot 3 \\
12 \cdot 6\end{array}$ & 160 & 294 \\
\hline All tumours & $\cdots$ & . & $\begin{array}{l}\text { Cases } \\
\text { Controls }\end{array}$ & $\begin{array}{l}1 \cdot 5 \\
1 \cdot 3\end{array}$ & $\begin{array}{l}1 \cdot 5 \\
1 \cdot 8\end{array}$ & $\begin{array}{l}1 \cdot 8 \\
1 \cdot 8\end{array}$ & $\begin{array}{l}1 \cdot 4 \\
1 \cdot 8\end{array}$ & $\begin{array}{r}9 \cdot 4 \\
11 \cdot 4\end{array}$ & $\begin{array}{l}9 \cdot 9 \\
9 \cdot 3\end{array}$ & $\begin{array}{l}12 \cdot 7 \\
14 \cdot 4\end{array}$ & $\begin{array}{l}12 \cdot 8 \\
12 \cdot 8\end{array}$ & 395 & 852 \\
\hline
\end{tabular}

*I = Motor-vehicle mechanics, machinists, miners 
TABLE II

RISK RATIOS AND THEIR 95\% CONFIDENCE INTERYALS FOR SELECTED HYDROCARBON-RELATED OCCUPATIONS OF FATHERS, BY AGE OF CHILD, AND DIAGNOSIS

\begin{tabular}{|c|c|c|c|c|c|c|c|c|c|c|}
\hline \multirow{3}{*}{\multicolumn{4}{|c|}{ Diagnosis }} & \multirow{4}{*}{$\begin{array}{l}\text { Age Group } \\
\text { (years) }\end{array}$} & \multicolumn{6}{|c|}{ Occupational Group* } \\
\hline & & & & & \multicolumn{2}{|c|}{$\mathbf{I}+\mathbf{I I}$} & \multicolumn{2}{|r|}{ III } & \multicolumn{2}{|c|}{$\mathbf{I}+\mathbf{I I}+\mathbf{I I I}$} \\
\hline & & & & & \multirow{2}{*}{$\begin{array}{c}\begin{array}{c}\text { Risk } \\
\text { Ratio }\end{array} \\
\begin{array}{c}0.33 \\
0 \cdot 50\end{array}\end{array}$} & $\begin{array}{l}\text { Confidence } \\
\text { Limits }\end{array}$ & \multirow{2}{*}{$\begin{array}{c}\begin{array}{c}\text { Risk } \\
\text { Ratio }\end{array} \\
0 \cdot 74 \\
1 \cdot 06\end{array}$} & $\begin{array}{l}\text { Confidence } \\
\text { Limits }\end{array}$ & \multirow{2}{*}{$\begin{array}{c}\begin{array}{c}\text { Risk } \\
\text { Ratio }\end{array} \\
0.68 \\
0.95\end{array}$} & $\begin{array}{c}\text { Confidence } \\
\text { Limits }\end{array}$ \\
\hline Leukaemia and & lym & $\operatorname{mas}$ & $\cdots$ & & & $\begin{array}{ll}0.01, & 4 \cdot 2 \\
0.11, & 1 \cdot 9\end{array}$ & & $\begin{array}{ll}0.34, & 1 \cdot 6 \\
0.63, & 1.8\end{array}$ & & $\begin{array}{ll}0.33, & 1 \cdot 4 \\
0.57, & 1.6\end{array}$ \\
\hline Brain tumours & . & $\cdots$ & $\cdots$ & $\begin{array}{l}<5 \\
<15\end{array}$ & $\begin{array}{l}4 \cdot 0 \\
1 \cdot 4\end{array}$ & $\begin{array}{ll}0.40, & 197 \\
0.50, & 3 \cdot 9\end{array}$ & $\begin{array}{l}0.17 \\
0.67\end{array}$ & $\begin{array}{ll}0.00, & 1 \cdot 4 \\
0.29, & 1 \cdot 5\end{array}$ & $\begin{array}{l}0.67 \\
0.88\end{array}$ & $\begin{array}{ll}0 \cdot 14, & 2 \cdot 8 \\
0 \cdot 46, & 1 \cdot 7\end{array}$ \\
\hline Other tumours & $\cdots$ & $\cdots$ & . & $<\underset{15}{5}$ & $\begin{array}{l}1.00 \\
0.67\end{array}$ & $\begin{array}{ll}0.27, & 3 \cdot 7 \\
0 \cdot 24, & 1 \cdot 8\end{array}$ & $\begin{array}{l}1 \cdot 1 \\
1 \cdot 4\end{array}$ & $\begin{array}{ll}0.53, & 2.4 \\
0.79, & 2.6 \\
\end{array}$ & $\begin{array}{l}1 \cdot 1 \\
1 \cdot 2\end{array}$ & $\begin{array}{ll}0.57, & 2 \cdot 1 \\
0.69, & 1 \cdot 9\end{array}$ \\
\hline All tumours & $\cdots$ & $\cdots$ & $\cdots$ & $\begin{array}{l}<5 \\
<15\end{array}$ & $\begin{array}{l}1 \cdot 10 \\
0 \cdot 82\end{array}$ & $\begin{array}{ll}0.42, & 2.9 \\
0.45, & 1.5\end{array}$ & $\begin{array}{l}0 \cdot 80 \\
1 \cdot 07\end{array}$ & $\begin{array}{ll}0.48, & 1 \cdot 3 \\
0.78, & 1 \cdot 5\end{array}$ & $\begin{array}{l}0.85 \\
1 \cdot 00\end{array}$ & $\begin{array}{ll}0 \cdot 54, & 1 \cdot 4 \\
0 \cdot 76, & 1 \cdot 3\end{array}$ \\
\hline
\end{tabular}

indication that matching had not materially enhanced validity or reduced efficiency (see Miettinen, 1970b).

\section{Discussion}

'The present case-control study was similar in general design to that of Fabia and Thuy (1974). The only difference lay in the source of information concerning the occupation of the father. In the Quebec study, the occupation was obtained from birth certificates, and consequently was that at the time of birth of the child; in our study, the relevant information was derived from the records of antenatal clinics and therefore related to the occupation during the first trimester of the pregnancy, and can be considered as representing the father's occupation at the time of conception. Furthermore, in the study of Fabia and Thuy (1974), the cases were children who had died of cancer; in the present study, they were incident cancer cases.

A high percentage of case-control pairs had to be discarded in the present study. There was a definite selection in regard to the time of birth of the pairs. The oldest children had been born in the mid-1940s and many of the records from that time, and from the early 1950 s, were no longer available. Nevertheless, the maintenance of individual matching during the course of analysis means that selection of this kind does not affect the results.

Contrary to the observations made by Fabia and Thuy (1974), the risk ratios of order 1 obtained in this study (Table II) suggest that the 'hydrocarbonrelated' occupation of the father at the time of conception is not a risk factor for subsequent malignant disease in the offspring. Excess risk could not be shown even in respect of motorvehicle mechanics, who had been characterized by a high risk in all of the main tumour categories in the Quebec study. However, we were unable to exclude the risk ratio of $2 \cdot 1$ obtained by Fabia and Thuy for children under five years of age.

Great differences are apparent in the percentage distributions of the occupational groups in Quebec and in Finland. The proportion of drivers, among the cases and controls combined, amounted tô about 10\% in Finland, and 6\% in Quebec. The most marked difference is observable with motor vehicle mechanics (included in group I), about $4 \%$ among the controls in Quebec but only $0.7 \%$ in this study. It is possible that some of the differences arose because of variation in the terminology of occupations, but the recording and classification of occupations seemed to be comparable in these two studies (J. Fabia, personal communication).

Requests for reprints: T. Hakulinen, Finnish Cancer Registry, Institute for Statistical and Epidemiological Cancer Research, Liisankatu 21B, Helsinki, Finland.

\section{REFERENCES}

FABIA, J. and THUY, T. D. (1974). Occupation of father at time of birth of children dying of malignant diseases. Brit. J. prev. soc. Med., 28, 98.

MiETtinen, O. S. (1970a). Estimation of relative risk from individually matched series. Biometrics, 26, 75.

- (1970b). Matching and design efficiency in retro. spective studies. Amer. J. Epidemiol., 91, 111.

SALONEN, T. and SAXÉN, L. (1975). Risk indicators in childhood malignancies. Int. J. Cancer, 15, 941.

Tepro, L., Hakama, M., Hakulinen, T., Lehtonen, M., and SAXÉN, E. (1975a). Cancer in Finland: Incidence, mortality, prevalence. Acta path. microbiol. scand., Sect. A, Suppl. 252.

SAlONEN, T., and Hakulinen, T. (1975b). Incidence of childhood cancer in Finland. J. nat. Cancer Inst., 55, 1065. 